УДК 338.242 .2

DOI: https://doi.org/10.37320/2415-3583/7.2

Данілова E.I.

кандидат економічних наук, доцент кафедри менеджменту зовнішньоекономічної діяльності підприємств, Національний авіаційний університет

\title{
ПОРІВНЯЛЬНИЙ АНАЛІЗ МЕТОДИК ОЦІНЮВАННЯ ЕКОНОМІЧНОЇ БЕЗПЕКИ ПІДПРИСМСТВ
}

\begin{abstract}
Метою статті є узагальнення методичного інструментарію оиінювання економічної безпеки підприємств, його порівняння та виявлення відповідності між задачами та наявними методами оцінювання рівня економічної безпеки підприємства. На основі аналізу наявної методологї, запропонованої в науковій економічній літературі для оцінювання економічної безпеки, узагальнено методи, конщептуальні підходи, критерї такого оцінювання. Поєднання ідентифікованих об 'єктів економічної безпеки та методів їх оцінювання дало змогу здійснити систематизацію наявного методичного інструментарію та виявити відповідність методик для виконання завдань оцінювання. Порівняльний аналіз наявних методів оцінювання економічної безпеки та їх відповідності задачам оиінювання дав змогу зробити висновок про необхідність розроблення комплексного підходу до оцінювання економічної безпеки, який би забезпечив можливість повного оцінювання як безпеки використання економічного потенціалу підприємства, так і безпеки реалізації економічних інтересів та умов діяльності як складових частин системи економічної безпеки.
\end{abstract}

Ключові слова: методика очінювання, економічна безпека, підхід до оцінювання, рівень економічної безпеки, критерій оцінювання.

Постановка проблеми. Властивостями сучасного зовнішнього середовища є нестабільність та невизначеність впливу, що формує загрози, небезпеки та ризики для діяльності підприємств. Зростання активності та збільшення інтенсивності їх впливів обумовлює необхідність управління економічною безпекою підприємств. Формування системи економічного захисту потребує розроблення концептуального підходу до їх оцінювання, який базувався б на кращих досягненнях економічної науки, давав би змогу комплексно оцінити джерела небезпек та ризиків, прогнозувати спрямованість їх впливу на стан стійкості та розвитку підприємства.

Аналіз останніх досліджень і публікацій. Методичні підходи до оцінювання економічної безпеки підприємства набули достатнього рівня досліджень у наукових публікація вітчизняних та іноземних науковців [1-19]. Однак більшість досліджень базується на оцінюванні функціональних підсистем економічної безпеки або використанні експертних методів оцінювання, які не забезпечують реалізацію принципу системності економічної безпеки.

Мета статті полягає в узагальненні методичного інструментарію оцінювання економічної безпеки підприємств, його порівнянні та виявленні відповідності задач оцінювання рівня економічної безпеки підприємства наявним методам.

Виклад основного матеріалу. Аналіз та узагальнення наявної методології, запропонованої в науковій економічній літературі для оцінювання економічної безпеки, дають змогу виокремити такі методологічні засади наявної системи науко- вих знань. Серед методів оцінювання економічної безпеки найчастіше застосовуються:

- статичний метод, заснований на оцінюванні стану економічної безпеки, корпоративних ресурсів, умов діяльності, ризиків авіакомпаніі, а також їх відхилення від нормативних значень або їх співвідношення;

- динамічний метод оцінювання тенденцій зміни показників економічної безпеки діяльності авіакомпанії.

Оцінювання економічної безпеки найчастіше здійснюється на основі оцінювання ресурсів підприємства, підсистем економічної безпеки, структурних підрозділів підприємства.

Методами отримання емпіричних даних для аналізу економічної безпеки є статистичні, експертні, баловий, метод рангів.

За концептуальним підходом до оцінювання стану економічної безпеки можна виокремити такі два підходи:

- діагностування входів в економічну систему підприємства (оцінювання зовнішніх та внутрішніх ризиків для діяльності підприємства) (ризикоорієнтований підхід);

- оцінювання та ретроспективний аналіз результатів діяльності попередніх періодів, які формують стартові позиції безпечності функціонування та розвитку підприємства в майбутніх періодах (результативний підхід).

Різними є погляди науковців на кількісний вимір стану економічної безпеки. Поширеними $є$ погляди науковців на оцінювання стану економічної безпеки на основі оцінювання прибутку підприємства [10, с. 67-69]. Позиція авторів 
грунтується на твердженні про те, що прибуток є індикатором стійкої безпечної діяльності в минулому, джерелом розвитку в майбутньому та ймовірним резервом покриття збитків від настання ризиків діяльності. Підтримуючи позицію зазначених авторів в тому, що важливим є врахування рівня прибутковості, оскільки прибуток є однією 3 основних цілей функціонування суб' єкта господарювання, доповнимо, що прибутковість у системі показників оцінювання критеріїв економічної безпеки (розвитку, стійкості, стабільності) є показником оцінювання рівня досяжності стабільності як критерію економічної безпеки підприємства. Окрім того, варто наголосити на тому, що економічна безпека підприємства як організаційна підсистема підприємства реалізує свої функції завдяки сукупності ресурсів, які вона використовує, а саме завдяки поєднанню технічних, інформаційних, матеріальних ресурсів та компетенцій персоналу підприємства, утримання та взаємодія яких вимагає відповідних джерел покриття інвестиційних та поточних витрат на забезпечення потреб економічної безпеки. В ланцюгу цих потреб прибуток є потенційним джерелом задоволення потреби їх фінансування.

Г.В. Козаченко, В.П.Пономарьов, О.М. Ляшенко [10] розглядають прибуток як джерело простого відтворення капіталу підприємства, яке, за методичним підходом автора, є умовою стану економічної безпеки.

Н.Н. Пойда-Носик [16] вважає, що показником оцінювання рівня економічної безпеки є ринкова вартість підприємства. Ринкову вартість підприємства в системі показників оцінювання діяльності підприємства більшість авторів навчальної літератури відносить до показників оцінювання ефективності діяльності підприємства. Однак 3 урахуванням різних підходів до визначення ринкової вартості підприємства (майновий, прибутковий, витратний, порівняльний) ціна ринкового попиту на підприємство не завжди прямо пропорційно корелює 3 прибутковістю його діяльності, оскільки на ціну акцій підприємства впливає сукупність факторів макро- й мезовпливу, особливо стану інвестиційної привабливості країни базування підприємства, перспектив розвитку галузі діяльності підприємства, стану конкуренції у вибраній галузі діяльності, психології покупців акцій підприємства тощо. 3 урахуванням сукупності висловлених обумовлень можна стверджувати, що показник ринкової вартості підприємства $\epsilon$ відображенням економічних інтересів усіх зацікавлених осіб підприємства, а саме власників, для яких ринкова вартість підприємства є довгостроковою метою діяльності підприємства, відповідно, всі стратегічні та поточні управлінські рішення спрямовуватимуться на забезпечення іï зростання, зокрема, через формування системи економічної безпеки, цільове призначення якої полягає в умовах безпечної діяльності для зростання ринкової вартості підприємства.

Прихильник функціонального підходу до оцінювання економічної безпеки С.M. Ілляшенко [7] дотримується позиції щодо визначення рівня економічної безпеки на основі розрахунку інтегрального показника, методика розрахунку якого $\epsilon$ усталеною й складається із сукупності таких укрупнених етапів:

1) виокремлення функціональних підсистем підприємства;

2) формування системи показників економічної безпеки для кожної функціональної підсистеми підприємства (показників розвитку, стійкості, стабільності, ефективності);

3) встановлення нормативних значень для сформованої вибірки показників (максимальних, мінімальних, рекомендованих, середньогалузевих тощо);

4) нормування фактичних значень показників відповідно до характеру їхнього впливу на стан економічної безпеки (стимулятори, дестимулятори);

5) визначення вагових коефіцієнтів одиничних показників у кожній підсистемі економічної безпеки на основі методу експертного опитування;

6) розрахунок одиничних зважених показників у кожній підсистемі;

7) розрахунок групового індексу кожної підсистеми економічної безпеки;

8) експертне оцінювання (ранжування) вагових коефіцієнтів групових індексів;

9) розрахунок інтегрального індексу економічної безпеки.

О.С. Іванілов [8] запропонував методику оцінювання ефективності функціонування системи економічної безпеки на основі розрахунку співвідношення різниці відверненої та заподіяної шкоди, поділеної на витрати на вжиття заходу. Таке співвідношення $\epsilon$ універсальним інструментарієм аналізу ефективності витрат на формування економічної безпеки, оскільки дає змогу оцінювати ефективність економічної безпеки на різних рівнях системи економічної безпеки, а саме на рівні окремих структурних підрозділів підприємства, на рівні відділу економічної безпеки та рівні підприємства загалом.

В.Ю. Халіна [19], О.В. Ілляшенко [6] критерієм економічної безпеки підприємства вважають формування можливостей розвитку, відповідно, оцінювання економічної безпеки пропонують здійснювати за допомогою оцінювання темпів зміни відповідних показників.

Розмаїття методичних підходів до оцінювання економічної безпеки обумовлено науковим різноманіттям позицій щодо кількісного визначення межі безпеки економічної діяльності підприємства. Так, В.П. Пономарьов [10] пов'язує 
межу економічної безпеки з достатністю власних ресурсів підприємства для забезпечення потреб простого відтворення 3 урахуванням постійних тенденцій інфляції засобів праці. При цьому джерелами простого відтворення $\epsilon$ амортизаційні відрахування та прибуток підприємства. Потреби простого відтворення формуються 3 вартості заміщення основних засобів підприємства, скоригованих на темп інфляції засобів праці. На основі співвідношення суми необхідного прибутку для забезпечення потреб простого відтворення та фактично отриманого прибутку підприємства автор пропонує визначати економічну безпеку підприємства.

Д.П. Пілова критерієм економічної безпеки вважає співвідношення раціонального чистого та фактичного прибутку підприємства. При цьому за раціональний обсяг прибутку приймається прибуток, який формує достатній обсяг ресурсів для фондів нагромадження та споживання [15].

С.М. Ілляшенко критерієм фінансової економічної безпеки вважає достатність обігових коштів для здійснення господарської діяльності [7].

О.В. Прокопішина [18] розмежовує поняття «економічна безпека підприємства» на дві його складові, такі як «економічна безпека стану підприємства» як стан захищеності від негативного впливу факторів зовнішнього й внутрішнього середовищ та «економічна безпека діяльності підприємства» як умови господарювання, в яких реалізуються його економічні інтереси. Відповідно до запропонованого розподілу понять автор пропонує виокремлювати економічну безпеку стану підприємства та економічну безпеку його діяльності. Економічну безпеку стану підприємства автор пропонує кількісно оцінити «на основі відхилення фактичних значень показників ефективності використання фінансових, матеріальних, трудових та інформаційних ресурсів (для обгрунтування інформаційної бази оцінювання використано кластерний аналіз) від оптимальних значень за ретроспективний період діяльності підприємства на основі задокументованих даних фінансового й управлінського обліків» $[18$, с. 6]. Оцінювання економічної безпеки діяльності пропонується на основі моделей нечіткого логічного висновку, які враховують випереджувальні сигнали прояву загроз за вибраними напрямами деталізації $[18$, с. 8$]$.

Поширеним є підхід до оцінювання рівня економічної безпеки на основі агрегування станів безпеки його підсистем, які вибираються залежно від галузі діяльності підприємства, його структури, рівня сформованості його економічної безпеки, джерел небезпек та ризиків тощо.

Для агрегування часткових показників складових підсистем економічної безпеки найчастіше використовуються методи адитивного згортання зважених часткових індикаторів та мультиплікативного згортання темпів зростання часткових індикаторів.

Для розрахунку комплексного показника оцінювання рівня економічної безпеки шляхом зведення показників оцінювання іiі складових науковцями використовуються різні наукові методи розрахунку індикаторів рівнів складових частин економічної безпеки підприємства. Так, науковою пропозицією В.Ю. Халіної є розрахунок темпів зміни показників оцінювання складових частин економічної безпеки з їх подальшим «виокремленням у розрізі характеру та напряму впливу на рівень економічної безпеки підприємства. При цьому показники, які прямують до збільшення, знаходяться у чисельнику формули визначення рівня певної складової економічної безпеки, а ті, що прямують до зменшення, - у знаменнику» $[19$, с. 179]. Відповідно, часткові індикатори складових частин економічної безпеки розраховуються як співвідношення добутку темпів зміни тих показників, які демонструють зростання, та добутку показників, які демонструють зниження.

В.Ю. Халіна та Т.Л. Зубко пропонують розраховувати рівень економічної безпеки підприємства у вигляді добутку часткових індикаторів складових частин економічної безпеки $[5 ; 19]$.

Для реалізації завдання прогнозування (моделювання) рівня економічної безпеки науковці використовують широкий арсенал таких методів:

- методи економіко-математичного прогнозування;

- імітаційне моделювання;

- метод нечіткої логіки [2; 5; 12; 13].

Щодо використання методичного інструментарію для моделювання рівня економічної безпеки, то в науковій літературі існують різні погляди на можливості та доцільність використання складних математичних моделей для прогнозування як рівня економічної безпеки, так і моделювання факторного впливу на його кількісне вираження. Така позиція обумовлена професійними компетенціями науковця, набутими в рамках відповідної галузі знань. Так, спеціалісти в галузі управління, не заперечуючи можливість використання складної математичної формалізації взаємозв'язків між показниками економічної безпеки підприємства, вказують на неможливість точної математичної формалізації економічної логіки та психології поведінки суб'єктів ринку й персоналу підприємства [16].

Інша група науковців [11] наголошує на необхідності застосування економіко-математичного моделювання для оцінювання рівня економічної безпеки, оскільки воно дає змогу виявляти фактори впливу на рівень економічної безпеки, моделювати сценарії поведінки рівня економічної безпеки за заданого впливу факторів. 
Отже, на основі короткого огляду наявної методології оцінювання економічної безпеки слід зауважити таке:

- вибраний методичний підхід до оцінювання повинен відповідати меті, яка формується відповідно до поставлених задач управління економічною безпекою;

- вибраний метод оцінювання реалізує задачу, а не мету оцінювання;

- наявність функціональних відмінностей у системі управління економічною безпекою та різної природи ризиків для діяльності підприємств вимагає застосування сукупності економічних та математичних методів дослідження;

- принцип адекватності реалізується через відповідність методу об'єкту оцінювання;

- принцип комплексності оцінювання формується за умови застосування методичного інструментарію, який був би заснований на оцінюванні як усіх функціональних підсистем економічної безпеки, так i всіх рівнів управління економічною безпекою;
- принцип узгодженості під час оцінювання економічної безпеки формується на засадах виявлення всіх видів залежностей між підсистемами економічної безпеки;

- оцінювання економічної безпеки базується на сукупності методів ретроспективного, теперішнього та прогнозованого стану економічної безпеки.

Поєднання ідентифікованих об'єктів економічної безпеки та методів їх оцінювання дає змогу систематизувати наявний методичний інструментарій. Відповідно до досліджених у науковій літературі об'єктів економічної безпеки сформована відповідність методик задачам дослідження (табл. 1).

Проведений аналіз методів оцінювання економічної безпеки на різних часових горизонтах управління дає змогу зробити висновки про необхідність забезпечення відповідності вибору методу визначеним задачам оцінювання. Оскільки економічна безпека підприємства характеризується як стан умов безпечності реалізації

Відповідність задач та методів оцінювання рівню економічної безпеки підприємства

\begin{tabular}{|c|c|c|}
\hline Задача оцінювання & Методи оцінювання & $\begin{array}{c}\text { Застереження у використанні } \\
\text { методу }\end{array}$ \\
\hline 1 & 2 & 3 \\
\hline $\begin{array}{l}\text { Формування емпіричних даних для оцінювання } \\
\text { ризиків, підсистем економічної безпеки, факторів } \\
\text { впливу на стан стійкості підприємства на основі } \\
\text { опитування спеціальної групи експертів }\end{array}$ & $\begin{array}{l}\text { Експертні методи } \\
{[1 ; 10]}\end{array}$ & $\begin{array}{l}\text { Наявність суб’єктивізму; } \\
\text { необхідність високих компетенцій } \\
\text { експертів у галузі діяльності та } \\
\text { предметній сфері аналізу. } \\
\end{array}$ \\
\hline $\begin{array}{l}\text { Систематизація, оброблення й аналіз даних } \\
\text { задля встановлення характерних для них } \\
\text { статистичних закономірностей, використання } \\
\text { для наукових і практичних висновків }\end{array}$ & $\begin{array}{l}\text { Методи математичної } \\
\text { статистики } \\
{[1 ; 6 ; 8]}\end{array}$ & $\begin{array}{l}\text { Використання для оброблення } \\
\text { емпіричних даних. }\end{array}$ \\
\hline $\begin{array}{l}\text { Приведення показників оцінювання до } \\
\text { безрозмірної величини }\end{array}$ & $\begin{array}{l}\text { Метод нормалізації } \\
{[1 ; 6 ; 8]}\end{array}$ & $\begin{array}{l}\text { Використання для оброблення } \\
\text { емпіричних даних. }\end{array}$ \\
\hline $\begin{array}{l}\text { Розрахунок комплексного показника рівня } \\
\text { економічної безпеки }\end{array}$ & $\begin{array}{l}\text { Методи згортки } \\
\text { (аддитивної, } \\
\text { мультиплікативної) } \\
{[1 ; 6 ; 8]}\end{array}$ & $\begin{array}{l}\text { Використання для оброблення } \\
\text { емпіричних даних. }\end{array}$ \\
\hline $\begin{array}{l}\text { Виявлення математичної залежності між } \\
\text { індексом економічної безпеки (зокрема, } \\
\text { прибутком) та вибраними факторами (ризиками, } \\
\text { показниками використання ресурсів, виконання } \\
\text { функцій тощо); надання за допомогою } \\
\text { коефіцієнтів кореляції порівняльної оцінки } \\
\text { щільності взаємозв’язку, який має певний } \\
\text { числовий вираз }\end{array}$ & $\begin{array}{l}\text { Кореляційно-регресійна } \\
\text { залежність } \\
{[1 ; 6 ; 8]}\end{array}$ & $\begin{array}{l}\text { Відображення лінійних } \\
\text { залежностей між факторами та } \\
\text { результатами. }\end{array}$ \\
\hline $\begin{array}{l}\text { Виявлення найбільш значущих факторів впливу } \\
\text { на стан економічної безпеки (на формування } \\
\text { економічного потенціалу, умов діяльності), } \\
\text { оцінювання ступеня їх впливу }\end{array}$ & $\begin{array}{l}\text { Факторний аналіз } \\
\text { (метод головних } \\
\text { компонент) } \\
{[17]} \\
\end{array}$ & $\begin{array}{l}\text { Необхідність формування } \\
\text { достовірної вибірки факторів. }\end{array}$ \\
\hline $\begin{array}{l}\text { Формування кластерів підприємств за рівнем } \\
\text { стану економічної безпеки, за фінансовим } \\
\text { станом, за ймовірністю банкрутства }\end{array}$ & $\begin{array}{l}\text { Кластерний аналіз } \\
{[13]}\end{array}$ & $\begin{array}{l}\text { Можливість використання } \\
\text { за наявності великої вибірки } \\
\text { підприємств; об’єктами } \\
\text { кластеризації є показники } \\
\text { результативності оцінювання. }\end{array}$ \\
\hline $\begin{array}{l}\text { Оцінювання факторів економічної безпеки } \\
\text { (ризиків), які є невизначеними, але які } \\
\text { впливають на иї стан }\end{array}$ & $\begin{array}{l}\text { Метод нечіткої логіки } \\
{[5 ; 7 ; 9 ; 13]}\end{array}$ & $\begin{array}{l}\text { Використання суб’єктивних } \\
\text { взаємозалежностей. }\end{array}$ \\
\hline
\end{tabular}


Продовження таблиці 1

\begin{tabular}{|l|l|l|}
\hline \multicolumn{1}{|c|}{1} & \multicolumn{1}{|c|}{2} & \multicolumn{1}{|c|}{3} \\
\hline $\begin{array}{l}\text { Моделювання рівня економічної безпеки; вибір } \\
\text { стратегій економічної безпеки }\end{array}$ & Сценарний підхід [3] & $\begin{array}{l}\text { Достовірність моделювання } \\
\text { досягається лише за умови } \\
\text { використання. }\end{array}$ \\
\hline $\begin{array}{l}\text { Прогнозування стану економічної безпеки } \\
\text { на основі продовження динамічного ряду на } \\
\text { майбутнє по виявленій закономірності }\end{array}$ & $\begin{array}{l}\text { Неможливість ідентифікації } \\
\text { часових рядів, які забезпечують } \\
\text { відповідність умов діяльності } \\
\text { мінливому зовнішньому } \\
\text { середовищу. }\end{array}$ \\
\hline $\begin{array}{l}\text { Оцінювання ймовірності банкрутства } \\
\text { йогія [14] }\end{array}$ & $\begin{array}{l}\text { Методи прогнозування } \\
\text { банкрутства } \\
\text { (багатофакторні } \\
\text { дискримінанті моделі) }\end{array}$ & Низька достовірність прогнозу. \\
\hline
\end{tabular}

Джерело: складено на основі джерел $[1 ; 3 ;$ 5-10; 13-14; 17$]$

iii функцій (шляхом використання ресурсів, реалізації економічного потенціалу, попередження небезпек та управління ризиками), комплексна система управління економічною безпекою базується на комплексній системі оцінювання ії стану, а остання - на комплексному поєднанні методів оцінювання для реалізації завдань оцінювання та досягнення її мети.

Аналіз методичного інструментарію оцінювання економічної безпеки дає змогу зробити висновок, що в основі вибору відповідного методу лежать задачі оцінювання, які укрупнено можна розподілити на задачі оцінювання економічної безпеки на основі вихідних потоків (результатів) та задачі оцінювання економічної безпеки на основі вхідних потоків (якими в контексті дослідження є ризики діяльності підприємства). Так, використання методів нечіткої логіки, сценарного підходу, експертного методу відбувається здебільшого для реалізації завдань оцінювання економічної безпеки на основі моделювання взаємозалежностей між вхідними факторами впливу на стан економічної безпеки. Економічні, статистичні методи, згортання часткових індикаторів використовуються переважно для оцінювання стану економічної безпеки на основі аналізу стану складових частин економічної безпеки.

Теоретичні дослідження сутності поняття «економічна безпека», «система економічної безпеки», «управління економічною безпекою» дають змогу зробити висновок про сутнісну багатогранність цього поняття, організаційну складність системи економічної безпеки та різну функціональну спрямованість управління економічною безпекою. Все це обумовлює висновок про необхідність комплексного поєднання в одному методичному підході аналізу вхідних небезпек та ризиків і небезпек та ризиків, які обумовлені попередніми результатами діяльності підприємства.

Таке поєднання є можливим на основі комбінування в єдиному методичному підході функціонально відповідних методик оцінювання, що вимагає нового концептуального підходу до оцінювання економічної безпеки підприємства.

Висновки. Порівняльний аналіз економічних, статистичних та математичних методів оцінювання, які використовуються в системі управління економічною безпекою, дає змогу зробити висновок про допустиму можливість реалізації задач оцінювання, оскільки всі вони володіють сукупністю обумовлень, різняться мірою складності використання, неоднозначністю інтерпретації результатів.

Системний характер економічної безпеки та складність взаємозв'язків у системі обумовлюють необхідність оцінювання економічної безпеки на основі використання комплексу методів, за допомогою яких досягаються визначені цілі оцінювання.

Методичний підхід до оцінювання економічної безпеки підприємства повинен мати комплексний характер і формуватися на основі поєднання методів оцінювання виокремлених його складових частин (економічної безпеки використання потенціалу, економічної безпеки реалізації відносин, економічної безпеки умов діяльності).

\section{Список використаних джерел:}

1. Васильців Т.Г. Економічна безпека підприємництва України: стратегія та механізми зміцнення : монографія. Львів : Арал, 2008. 386 с.

2. Горячева К.С. Фінансова безпека підприємства. Сутність та місце в системі економічної безпеки. Економіст. 2003. № 8. C. $65-67$.

3. Гриценко В.І., Бажан Л.І. Сиенарне моделювання рівня безпеки розвитку економічної системи в умовах невизначеності. Наука та наукознавство. 2014. С. 58-65.

4. Зима Л.М. Організаційно-економічні механізми управління економічною безпекою підприємств стратегічного значення : автореф. дис. ... канд. екон. наук : спец. 08.06.01. Донецьк, 2004. 12 с. 
5. Зубко Т.Л. Методика визначення економічної безпеки підприємства. Економіка. Менеджмент. Бізнес. 2016. № 2. C. 69-76.

6. Ілляшенко О.В. Методологічні засади формування та функціонування механізмів системи економічної безпеки підприємства : дис. ... докт. екон. наук : спец. 08.00.04. Київ, 2016. 606 с.

7. Ілляшенко С.М. Складові економічної безпеки підприємства і підходи до їх оцінки. Актуальні проблеми економіки. 2003. № 3. С. 12-19.

8. Іванілов О.С. Економіка підприємства. URL: https://pidruchniki.com/16250212/ekonomika/metodi_otsinyuvannya rivnya_ekonomichnoyi_bezpeki_pidpriyemstva.

9. Ковальов Д.В., Плєтнікова І.М. Кількісна оцінка рівня економічної безпеки підприємства. Економіка Украӥни. 2008. № 4. С. 35-40.

10. Козаченко Г.В., Пономарьов В.П., Ляшенко О.М. Економічна безпека підприємства: сутність та механізм забезпечення : монографія. Київ : Лібра, 2003. 280 с.

11. Кокнаєва М.О. Особливості формування методичного інструментарію дослідження фінансово-економічної безпеки торговельних підприємств. Економічний часопис - XXI. 2012. № 5-6. С. 53-55.

12. Марущак С.М. Методика оцінки рівня економічної безпеки підприємства на основі теорії нечітких множин. Вісник Хмельницького національного університету. Економічні науки. 2011. № 5. Т. 1. С. 16-21.

13. Меліхова Т.О. Оцінка рівня економічної безпеки підприємства за допомогою нейронних мереж та кластерного аналізу. Східна Європа: економіка, бізнес та управління. 2018. № 12. С. 407-417.

14. Мищенко С.Н. Система обеспечения экономической безопасности организации : дисс. ... канд. экон. наук : спец. 08.00.05. Ростов-на-Дону, 2004. 197 с.

15. Пілова Д.П. Формування та оцінка економічної безпеки гірничо-збагачувальних підприємств : автореф. дис. ... канд. екон. наук : спец. 08.00.04. Кривий Ріг, 2007. 16 с.

Пойда-Носик Н.H. Науково-методичні підходи до оцінки рівня фінансової безпеки підприємства. URL: http://nbuv.gov.ua/UJRN/Tpaeiv_2013_1_1_64 (дата звернення: 30.01.2020).

16. Посилаєва К.І. Факторний аналіз у дослідженні показників господарської діяльності. URL: http://magazine.faaf.org.ua/faktorniy-analiz-u-doslidzhenni-pokaznikiv-gospodarskoi-diyalnosti.html (дата звернення: 10.01.2020).

17. Прокопішина О.В. Управління економічною безпекою зовнішньоекономічної діяльності підприємства : автореф. дис. ... канд. екон. наук : спец. 08.00.04. Харків, 2009. 20 с.

18. Халіна В.Ю. Методичний підхід щодо оцінки рівня економічної безпеки підприємства. Вісник Чернівецького торговельно-економічного інституту. Економічні науки. 2014. № 1. С. 173-181.

\section{References:}

1. Vasyltsev, T.G. (2008), Ekonomichna bezpeka pidpryiemnytstva Ukrainy: stratehiia ta mekhanizmy zmitsnennia: monohrafiia [Economic security of entrepreneurship of Ukraine: strategy and mechanisms of strengthening: monograph], Aral, Lviv. Ukraine.

2. Goryacheva, K.S. (2003), "Financial security of the enterprise. The essence and place in the economic security system", Ekonomist, vol. 8, pp. 65-67.

3. Gritsenko, V.I. and Bazhan, L.I. (2014), "Scenario modeling of the level of security of economic system development under uncertainty", Nauka ta naukoznavstvo, pp. 58-65.

4. Zyma, L.M. (2004), "Organizational and economic mechanisms of economic security management of enterprises of strategic importance", Ph.D. Thesis, 08.06.01, Donetsk, Ukraine.

5. Zubko, T.L. (2016), "Methods of determining the economic security of the enterprise", Ekonomika. Menedzhment. Biznes, vol. 2, pp. 69-76.

6. Ilyashenko, O.V. (2016), "Methodological bases of formation and functioning of mechanisms of the enterprise economic security system", Abstract of Doctor of Economic Science dissertation, 08.00.04, Kyiv, Ukraine.

7. Ilyashenko, S.M.(2003), "Components of enterprise economic security and approaches to their assessment", Aktual'ni problemy ekonomiky, vol. 3, pp. 12-19.

8. Ivanilov. O.S. (2009), "Business Economics" [Online], available at: https://pidruchniki.com/16250212/economics/ metodi_otsinyuvannya_rivnya_ekonomichnoyi_bezpeki_pidpriyemstva.

9. Kovalev, D.V. and Pletnikov, I.M. (2008), "Quantitative assessment of the level of economic security of the enterprise", Ekonomika Ukrainy, vol. 4, pp. 35-40.

10. Kozachenko, G.V. Ponomaryov, V.P. and Lyashenko, O.M. (2003), Ekonomichna bezpeka pidpryiemstva: sutnist' ta mekhanizm zabezpechennia: monohrafiia [Economic security of the enterprise: essence and mechanism of providing: monograph], Libra, Kyiv, Ukraine.

11. Koknaeva, M.O. (2012), "Features of formation of methodological toolkit of study of financial and economic security of trade enterprises", Ekonomichnyj chasopys - XXI, vol. 5-6, pp. 53-55.

12. Marushchak, S.M. (2011), "Methods of estimating the level of economic security of an enterprise based on fuzzy set theory", Visnyk Khmel'nyts'koho natsional'noho universytetu. Ekonomichni nauky, vol. 5, t. 1, pp. 16-21.

13. Melikhova, T.O. (2018), "Estimation of the level of economic security of the enterprise using neural networks and cluster analysis", Skhidna Yevropa: ekonomika, biznes ta upravlinnia, vol. 12, pp. 407-417.

14. Mishchenko, S.N. (2004), "System of providing economic security of the organization", Ph.D. Thesis, 08.00.05, Rostovon-Don, Russian Federation. 
15. Pilova, D.P. (2007), "Formation and assessment of economic security of mining and processing enterprises", Ph.D. Thesis, 08.00.04, Kriviy Rig, Ukraine.

Poida-Nosyk, N.N.(2013), "Scientific and methodological approaches to the assessment of the level of financial security of the enterprise" [Online], available at: http://nbuv.gov.ua/UJRN/Tpaeiv_2013_1_1_64 (accessed: 30 Jan 2020).

Posylayeva, K.I. (2007), "Factor analysis in the study of economic indicators" [Online], available at: http://magazine.faaf.org.ua/faktorniy-analiz-u-doslidzhenni-pokaznikiv-gospodarskoi-diyalnosti.html (accessed: 10 Jan 2020).

Prokopishina, O.V. (2009) "Management of economic security of foreign economic activity of the enterprise”, Ph.D. Thesis, 08.00.04, Kharkiv, Ukraine.

Khalina, V.Y. (2014), "Methodical approach to assessing the level of economic security of an enterprise", Visnyk Chernivets'koho torhovel'no-ekonomichnoho instytutu. Ekonomichni nauky, vol. 1, pp. 173-181.

Danilova Elvira

National Aviation University

\section{COMPARATIVE ANALYSIS OF METHODS OF EVALUATION OF ENTERPRISES' ECONOMIC SECURITY}

The characteristics of the modern external environment are instability and uncertainty of influence, which creates dangers and risks for the activity of enterprises. Increase in activity and increase of intensity of their influence causes necessity of management of economic safety of the enterprises. The aim of the article is to generalize methodical tools of evaluation of enterprises' economic security, to compare them and to show consistencies between tasks and existing methods of evaluation of the level of enterprises 'economic security. Methods, conceptual approaches and evaluation criteria are generalized on the basis of existing methodology analysis that was given in scientific economic literature for the evaluation of enterprises' economic security. The combination of the identified economic security objects and the methods of their evaluation allowed to conduct systematization of existing methodological instruments and to show consistencies of methodologies for implementation of evaluation tasks. Comparative analysis of existing methods of evaluation of enterprises' economic security and compliance of these methods with the tasks of evaluation allowed to draw a conclusion that there is a necessity to develop integrated approach for the evaluation of economic security, that would offer the possibility of thorough evaluation of security of usage of enterprise's economic potential, security of economic interests and operational environment as components of economic security system. The systemic nature of economic security and the complexity of the interconnections in the system necessitate the assessment of economic security on the basis of the use of a set of methods that realize the defined objectives of the assessment. Methodical approach to the assessment of the economic security of the enterprise should be complex and formed on the basis of a combination of methods of assessing its separate components (potential use, relations, and conditions of activity).

Key words: methodology of evaluation, economic security, evaluation approach, the level of economic security, evaluation criteria.

JEL classification: M21. 